\title{
UPAYA PENCEGAHAN JUMLAH PENDERITA PNEUMONI DI MASYARAKAT DI ERA PANDEMI COVID 19
}

\author{
Nanta Sigit ${ }^{1)}$, Romaden Marbun ${ }^{1)}$ \\ ${ }^{1)}$ Manajemen Informasi Kesehatan, STIKes Panti Waluya Malang, Malang, Jawa Timur, Indonesia \\ Corresponding author : Nanta Sigit \\ E-mail : Nantasigit1991@gmail.com
}

Diterima 22 Juli 2021, Direvisi 01 Agustus 2021, Disetujui 01 Agustus 2021

\begin{abstract}
ABSTRAK
Kegiatan pengadian kepada masyarakat "upaya pencegahan jumlah penderita pneumoni di masyarakat di era pandemi covid 19" dengan bertujuan untuk mengimplementasikan program berbasis masyarakat yang memfasilitasi masyarakat dalam membentuk kelompok masyarakat peduli penurunan penderita pneumonia dan menambah ilmu dan perilaku yang baik tentang penatalaksanaan pneumonia. Jenis penelitian ini adalah quasi eksperimental design (eksperimen semu), dengan rancangan non equivalent control group design. Pengetatuan kader dan tokoh masyarakat diukur dengan menggunakan kuesioner Uji perbedaan menggunakan uji paired T-test. Penelitian ini dilakukan pada 46 responden, hasil penelitian ini menunjukan bahwa sebelum dilakukan penyuluhan yang pengetahuan baik yaitu 30,43\% dan yang mempunyai pengetahuan tidak baik yaitu $69,57 \%$. Setelah dilakukan penyuluhan terjadi peningkatan pengetahuan, yang berpengetahuan baik yaitu $69,57 \%$ dan yang pengetahuannya tidak baik yaitu $30,43 \%$. Perbedaan pengetahuan penyakit PNEUMONIA diperoleh nilai $(p=0,000)$ menunjukaan ada perbedaan pengetahuan pneumonia sebelum dan sesudah diberi penyuluhan tentang penyakit pneumonia dengan menggunakan media video dan power point.
\end{abstract}

Kata kunci: penyakit pneumonia; penyuluhan dengan media video.

\begin{abstract}
Community service activities "efforts to prevent the number of pneumonic patients in the community in the pandemic covid 19 era" with the aim of implementing community-based programs that facilitate the community in forming community groups to care for the reduction of pneumonia sufferers and to increase knowledge and good behavior regarding pneumonia management. This type of research is a quasi experimental design (quasi-experimental), with a non equivalent control group design. The arrangement of cadres and community leaders was measured using a questionnaire. The difference test used the paired t-test. This research was conducted on 46 respondents, the results of this study showed that before counseling was carried out, those who had good knowledge were $30.43 \%$ and those who had bad knowledge were $69.57 \%$. After counseling was done, there was an increase in knowledge, those with good knowledge were $69.57 \%$ and those with bad knowledge were $30.43 \%$. The difference in knowledge of pneumonia disease was obtained by value $(p=0.000)$ indicating that there was a difference in pneumonia knowledge before and after being given education about pneumonia disease using video and powerpoint media.
\end{abstract}

Keywords: pneumonia disease; information with video media.

\section{PENDAHULUAN}

Pada umumnya, pneumonia

dikategorikan dalam penyakit menular yang ditularkan melalui udara, dengan sumber penularan adalah penderita pneumonia yang menyebarkan kuman dalam bentuk droplet ke udara pada saat batuk atau bersin. Untuk selanjutnya, kuman penyebab pneumonia masuk ke saluran pernapasan melalui proses inhalasi (udara yang dihirup), atau dengan cara penularan langsung, yaitu percikan droplet yang dikeluarkan oleh penderita saat batuk, bersin, dan berbicara langsung terhirup oleh orang di sekitar penderita, atau memegang dan menggunakan benda yang telah terkena sekresi saluran pernapasan penderita. Sampai saat ini, penyakit pneumonia merupakan penyebab utama kematian balita di dunia. Diperkirakan ada 1,8 juta atau 20\% dari kematian anak diakibatkan oleh pneumonia, melebihi kematian akibat AIDS, malaria dan tuberkulosis. Adanya Pneumonia ditandai dengan batuk dan kesulitan bernapas yaitu napas cepat, dan tarikan dinding dada bagian bawah ke dalam. 
Di Indonesia, pneumonia juga merupakan urutan kedua penyebab kematian pada balita setelah diare. Riset Kesehatan Dasar (Riskesdas) melaporkan bahwa kejadian pneumonia sebulan terakhir (period prevalence) mengalami peningkatan pada tahun 2007 sebesar 2,1\%o menjadi 2,7\%o pada tahun 2013. Kematian balita yang disebabkan oleh pneumonia tahun 2007 cukup tinggi, yaitu sebesar 15,5\%.2,3 Demikian juga hasil Survei Demografi dan Kesehatan Indonesia (SDKI), yang melaporkan bahwa prevalensi pneumonia dari tahun ke tahun terus meningkat, yaitu 7,6\% pada tahun 2002 menjadi $11,2 \%$ pada tahun 2007.

Pneumonia merupakan penyakit dari paru-paru dan sistem pernapasan dimana alveoli (mikroskopik udara mengisi kantong dari paru yang bertanggung jawab untuk menyerap oksigen dari atmosfer) menjadi radang dan dengan penimbunan cairan. Pneumonia disebabkan oleh berbagai macam sebab,meliputi infeksi karena bakteri,virus,jamur atau parasit. Pneumonia juga dapat terjadi karena bahan kimia atau kerusakan fisik dari paru- paru,atau secara tak langsung dari penyakit lain seperti kanker paru atau penggunaan alkohol. Gejala khas yang berhubungan dengan pneumonia meliputi batuk,nyeri dada demam,dan sesak nafas.Alat diagnosa meliputi sinar- $x$ dan pemeriksaan sputum.Pengobatan tergantung penyebab dari pneumonia; pneumonia kerena bakteri diobati dengan antibiotika. Pneumonia merupakan penyakit yang umumnya terjadi pada semua kelompok umur, dan menunjukan penyebab kematian pada orang tua dan orang dengan penyakit kronik.Tersedia vaksin tertentu untuk pencegahan terhadap jenis pnuemonia. Prognosis untuk tiap orang berbeda tergantung dari jenis pneumonia, pengobatan yang tepat,ada tidaknya komplikasi dan kesehatan orang tersebut Kementerian Kesehatan Republik Indonesia.

Sampai dengan tahun 2013, angka cakupan penemuan pneumonia balita tidak mengalami perkembangan berarti yaitu berkisar antara 23\%-27\%. Selama beberapa tahun terakhir cakupan penemuan pneumonia tidak pernah mencapai target nasional, termasuk target tahun 2013 yang sebesar $80 \%$. Angka kematian akibat pneumonia pada balita sebesar $1,19 \%$. Pada kelompok bayi angka kematian lebih tinggi yaitu sebesar 2,89\% dibandingkan pada kelompok umur 1-4 tahun yang sebesar $0,20 \%$.

Pneumonia adalah penyakit yang disebabkan kuman pneumococcus, staphylococcus, streptococcus, dan virus. Gejala penyakit pneumonia yaitu menggigil, demam, sakit kepala, batuk, mengeluarkan dahak, dan sesak napas. Populasi yang rentan terserang pneumonia adalah anak-anak usia kurang dari 2 tahun, usia lanjut lebih dari 65 tahun dan orang yang memiliki masalah kesehatan (malnutrisi, gangguan imunologi). Menurut hasil Riskesdas

2013, period prevalence pneumonia berdasarkan diagnosis selama 1 bulan sebelum wawancara sebesar $0,2 \%$. Sedangkan berdasarkan diagnosis/gejala sebesar $1,8 \%$. Dibandingkan dengan hasil Riskesdas 2007 yang sebesar $2,13 \%$, period prevalence pneumonia berdasarkan diagnosis/gejala pada tahun 2013 mengalami penurunan menjadi $1,8 \%$.Pada balita, period prevalence berdasarkan diagnosis sebesar 2,4 per 1.000 balita dan berdasarkan diagnosis/gejala sebesar 18,5 per 1.000 balita.

\section{METODE}

Program pengabdian pada masyarakat ini dilakukan di Desa Tumpeng Krajan, Kabupaten Lumajang pada Bulan Januari Februari 2021. Khalayak sasran yaitu para kader kesehatan dan masyarakat di Desa Karang Anyar dengan jumlah 46 orang. Metode dilakukan berupa penyuluhan dan diskusi interaktif yang dilakukan secara daring dan luring. Secara luring dilaksanakn di salah satu rumah kader kesehatan, dan secara daring dilakukan melalui grup Whatsapp. Materi yang disampaikan adalah bagaimana upaya pencegahan penyakit Pneumoni.

Sebelum melakukan kegiatan pengabdian masyarakat ini, pengabdi melakukan pertemuan terbatas dengan para kader kesehatan untuk menentukan metode dan waktu pengabdian pada masyarakat. Dari hasil pertemuan dengan kader kesehatan disepakati kegiatan pada masyarakat ini dilakukan sebanyak 2 kali dalam pemberian materi. Evaluasi kegiatan dilakukan di akhir kegiatan, melalui google form guna mengetahui tingkat pemahamam peserta kegiatan.

\section{HASIL DAN PEMBAHASAN Karakteristik Responden Menurut Jenis Kelamin dan Umur}

Pengumpulan data dilakukan dengan menggunakan kuesioner terhadap 46 sampel di kabupaten lumajang. Berdasarkan hasil pengumpulan data karakteristik responden menurut jenis kelamin dan umur dapat dilihat pada Tabel 1 berikut:

Tabel 1. Distribusi Responden Menurut Jenis Kelamin dan Umur $(\mathrm{N}=46)$ 


\begin{tabular}{lcc}
\hline Jenis Kelamin & Jumlah $(\mathrm{n})$ & Presentase $(\%)$ \\
\hline Laki-laki & 26 & 56.52 \\
\hline Perempuan & 20 & 43.47 \\
\hline Umur (Th) & Jumlah $(\mathrm{n})$ & Presentase $(\%)$ \\
\hline $20-30$ & 21 & 45.7 \\
\hline $31-40$ & 22 & 47.8 \\
\hline $41-50$ & 3 & 6.5 \\
\hline
\end{tabular}

Tabel 1 menunjukkan karakteristik responden yang dilibatkan dalam penelitian ini. Diketahui bahwa responden berjenis kelamin laki-laki yaitu sebanyak 26 orang $(56.52 \%)$, dan yang berjenis kelamin perempuan sebanyak 20 orang $(43.47 \%)$. Sedangkan, usia responden 20-30 tahun sebanyak 21 orang (45.7\%), usia 31- 40 tahun sebanyak 22 orang (47.8\%), dan usia 41-50 tahun sebanyak 3 orang (6.5\%).

\section{Rata-Rata Nilai Pengetahuan Sampel}

Peresentase pengetahuan responden sebelum diberi penyuluhan tentang penyakit PNEUMONIA diperoleh rata-rata 70,978, dengan nilai minimum 50 dan nilai maksimum 85 , sedangkan peresentase pengetahuan responden sesudah diberi penyuluhan tentang penyakit PNEUMONIA diperoleh rata-rata $80,87 \%$, dengan nilai minimum 55 dan nilai maksimum 95. Distribusi rata-rata pengetahuan penyakit pneumonia sebelum dan sesudah diberi penyuluhan dengan menggunakan media video dan power point dapat dilihat pada Table 2 berikut:

Tabel 2. Nilai Rata-Rata Pengetahuan Sebelum dan Sesudah diberi Penyuluhan penyakit pneumonia

\begin{tabular}{|c|c|c|c|}
\hline $\begin{array}{l}\text { Variabel } \\
\text { Pengetahuan }\end{array}$ & $\begin{array}{l}\text { Nilai } \\
\text { Minimum }\end{array}$ & $\begin{array}{l}\text { Nilai } \\
\text { Maksimum }\end{array}$ & $\begin{array}{l}\text { Rata- } \\
\text { rata }\end{array}$ \\
\hline $\begin{array}{l}\text { Sebelum } \\
\text { diberi } \\
\text { penvuluhan }\end{array}$ & 50 & 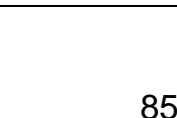 & 70.978 \\
\hline $\begin{array}{l}\text { Sesudah } \\
\text { diberi } \\
\text { penyuluhan }\end{array}$ & 55 & 95 & 80.87 \\
\hline
\end{tabular}

\section{Tingkat Pengetahuan}

Distribusi frekuensi pengetahuan penyakit PNEUMONIA sebelum dan sesudah diberi penyuluhan dengan menggunakan media power point dapat dilihat pada Tabel 3.

Tabel 3. Distribusi Frekuensi Pengetahuan penyakit PNEUMONIA Sebelum dan Sesudah diberi Penyuluhan Dengan
Menggunakan Media Power Point

\begin{tabular}{ccccc}
\hline & \multicolumn{2}{c}{ Sebelum } & \multicolumn{2}{c}{ Sesudah } \\
\cline { 2 - 5 } Pengetahuan & $\mathrm{N}$ & $\%$ & $\mathrm{~N}$ & $\%$ \\
\hline Baik & 14 & 30.43 & 32 & 69.57 \\
\hline Tidak & 32 & 69.57 & 14 & 30.43 \\
\hline Jumlah & 46 & 100 & 46 & 100 \\
\hline
\end{tabular}

Hasil penelitian ini menunjukan bahwa sebelum dilakukan penyuluhan tentang penyakit PNEUMONIA sampel dikategorikan memiliki pengetahuan baik yaitu $30,43 \%$ dan yang mempunyai pengetahuan tidak baik yaitu $69,57 \%$. Setelah dilakukan penyuluhan tentang penyakit PNEUMONIA dengan menggunakan media video dan power point terjadi peningkatan pengetahuan, sampel yang berpengetahuan baik yaitu $69,57 \%$ dan yang pengetahuannya tidak baik yaitu $30,43 \%$.

Faktor yang mempengaruhi tingkat pengetahuan salah satunya adalah dengan penyuluhan menggunakan media video dan power point, hal ini dapat terlihat dengan meningkatnya pengetahuan responden dari sebelum penyuluhan dan sesudah penyuluhan dengan menggunakan media power point.

\section{Perbedaan Pengetahuan Penyakit PNEUMONIA Sebelum dan Sesudah Diberi Penyuluhan dengan Menggunakan Media Video dan Power Point}

Perbedaan Pengetahuan Penyakit PNEUMONIA Sebelum dan Sesudah Diberi Penyuluhan Tentang Penyakit PNEUMONIA dengan Menggunakan Video dan Media Power Point tersaji pada Tabel 4.

Tabel 4. Hasil Paired Samples Test

\begin{tabular}{cccc}
$\begin{array}{c}\text { Variabel } \\
\text { Pengetahuan }\end{array}$ & Mean & $p$-Value & Keputusan \\
\hline $\begin{array}{c}\text { sebelum } \\
\text { penyuluhan }\end{array}$ & 70.978 & 0.00 & H0 ditolak \\
\hline $\begin{array}{c}\text { setelah } \\
\text { penyuluhan }\end{array}$ & 80.87 & 0.00 & H0 ditolak \\
\hline
\end{tabular}

Tabel 4 menunjukkan uji statistik dengan menggunakan uji Paired Samples Test untuk pengetahuan penyakit PNEUMONIA sebelum dan sesudah diberi penyuluhan tentang penyakit PNEUMONIA dengan menggunakan media video dan power point. Hasil uji menunjukkan nilai $p<0,05$ artinya ada perbedaan pengetahuan penyakit PNEUMONIA sebelum dan sesudah diberi 
penyuluhan tentang penyakit PNEUMONIA dengan menggunakan media video dan power point. Penyuluhan merupakan salah satu upaya untuk memberikan informasi, semakin banyak informasi yang didapat maka akan mempunyai pengetahuan yang lebih luas (Sukanto, 2010).

Menurut Notoatmodjo (2012), power point merupakan salah satu alat peraga yang berfungsi sebagai alat bantu untuk memaparkan atau mempresentasikan sebuah materi (penyakit PNEUMONIA). Keunggulan power point antara lain: materi menjadi lebih menarik karena ada permainan warna, huruf dan animasi, baik animasi teks maupun animasi gambar atau foto. Pesan informasi secara visual mudah dipahami kader dan tokoh masyarakat dan lebih merangsang anak untuk mengetahui lebih jauh informasi tentang bahan ajar yang tersaji.

Penggunaan media pembelajaran (dalam hal ini video dan power point) dapat membuat kader kesehatan lebih aktif dan antusias, hal ini sesuai dengan pendapat Sudjana dan Ahmad Rivai (2011) yang mengungkapkan bahwa manfaat media dalam proses memberikan materi edukasi diantaranya ialah materi akan menarik perhatian kader kesehatan sehingga dapat menimbulkan motivasi dalam proses memahami materi, bahan ajar akan lebih jelas maknanya sehingga dapat lebih mudah dipahami oleh kader kesehatan, dan kader lebih memahami atau menguasai tujuan dari pembelajaran yang lebih baik. Metode pembelajaran dengan media akan lebih bervariasi karena tidak semata-mata komunikasi verbal melalui penuturan kata-kata oleh pemateri sehingga kader kesehatan tidah mudah bosan.

\section{SIMPULAN DAN SARAN}

Tingkat pengetahuan penyakit PNEUMONIA sebelum dilakukan penyuluhan tentang penyakit PNEUMONIA dengan menggunakan media video dan power point yaitu 14 orang $(30,43 \%)$ mempunyai pengetahuan baik, dan 32 orang $(69,57 \%)$ mempunya pengetahuan tidak baik.

Tingkat pengetahuan penyakit PNEUMONIA setelah dilakukan penyuluhan tentang penyakit PNEUMONIA dengan menggunakan media video dan power point mengalami peningkatan pengetahuan, yaitu 32 orang $(69,57)$ mempunyai pengetahuan baik, dan yang berpengetahuan tidak baik hanya 14 orang $(30,43 \%)$.

Perbedaan pengetahuan penyakit PNEUMONIA diperoleh nilai $\mathrm{p}=0,000$ menunjukaan ada Perbedaan pengetahuan penyakit PNEUMONIA sebelum dan sesudah diberi penyuluhan tentang penyakit PNEUMONIA dengan menggunakan media video dan power point.

\section{UCAPAN TERIMAKASIH}

Saya ucapkan banyak terimakasih kepada Ketua STIKes Panti Waluya, LPPM dan Ibu Widi Selaku Ketua Prodi MIK STIKes Panti Waluya Malang.

\section{DAFTAR RUJUKAN}

Anwar, Athena, \& Dharmayanti, Ika. (2014). Pneumonia pada Anak Balita di Indonesia. Jurnal Kesehatan Masyarakat Nasional, 8(8). doi: http://dx.doi.org/10.21109/kesmas.v8i8 .405

Badan Pusat Statistik, Badan Kependudukan dan Keluarga Berencana Nasional, Departemen Kesehatan. (2013). Survei demografi dan kesehatan Indonesia Tahun 2007

Departemen Kesehatan RI. Riset kesehatan dasar (Riskesdas). Jakarta. Badan Penelitian dan Pengembangan Kesehatan Departemen Kesehatan RI. 2010 (diunduh 3 Januari 2021). Tersedia dari: URL: http://www.litbang.depkes.go.id/sites/ download/buku laporan/lapnas riskes da s2010/Laporan riskesdas 2010. Pdf.

Efni, Yulia, Machmud, Rizanda, \& Pertiwi, Dian. (2016). Faktor Risiko yang Berhubungan dengan Kejadian Pneumonia pada Balita di Kelurahan Air Tawar Barat Padang. Jurnal Kesehatan Andalas, 5(2). doi: https://doi.org/10.25077/jka.v5i2.523

INDONESIA, KEMENTERIAN KESEHATAN REPUBLIK. (2016). Pedoman Tatalaksana Klinis Infeksi Saluran Pernapasan Akut Berat Suspek. from http://www.p2ptm.kemkes.go.id/dokum en-ptm/pedoman-tatalaksana-klinisinfeksi-saluran-pernapasan-akut-beratsuspek

Niederman, Michael S, \& Ahmed, Qanta A A. (2003). Community-acquired pneumonia in elderly patients. National Library of Medicine, 19(1), 101-120. doi: 10.1016/s0749-0690(02)00061-7

Patria, Muhammad Arafat. (20). Faktor Risiko Pneumonia pada Balita di Indonesia: Narative Review Penelitian Akademik Bidang Kesehatan Masyarakat. Jurnal Fakultas Kesehatan Masyarakat, 10(2), 2019. doi: 
http://dx.doi.org/10.12928/kesmas.v10i 2.4231

Rudan, Igor, Boschi-Pinto, Cynthia, Biloglav, Zrinka, Mulhollandd, Kim, \& e, Harry Campbell. (2008). Epidemiology and etiology of childhood pneumonia. Bulletin of the World Health Organization, 86(5). doi: 10.2471/BLT.07.048769

Sari, Elza Febria, Rumende, C Martin, \& Harimurti, Kuntjoro. (2016). FaktorFaktor yang Berhubungan dengan Diagnosis Pneumonia pada Pasien Usia Lanjut. Penyakit Dalam Indonesia, 3(4).

doi: http://dx.doi.org/10.7454/jpdi.v3i4.51 